\title{
DRESS CODES IN SCHOOLS: A TALE OF HEADSCARVES AND HAIRSTYLES
}

\author{
Fatima Osman \\ B Bus Sci Law LLB LLM \\ Lecturer, University of Cape Town \\ Jean Wilké \\ $B A$ LLB LLM (Hons) \\ Lecturer, University of Cape Town
}

SUMMARY

In 2016 independent or private schools made headlines as learners protested the codes of conduct of various schools and the lack of accommodation of African hairstyles. The question of a school's autonomy to enact a code of conduct and prohibit certain religious or cultural dress is not new and there has been worldwide controversy regarding schools banning the Islamic headscarf. This article examines the obligation of South African public and independent schools to accommodate the headscarf and diverse hairstyles. It argues that the Islamic headscarf is a central tenet of the Islamic faith protected by the constitutional right to religious freedom and that given the current guidelines on school uniforms, public schools are bound to accommodate the headscarf. The matter is more nuanced with independent schools that may be established in the pursuit of a religious ethos. The article argues that independent schools are equally prohibited from discrimination on religious and cultural grounds and must demonstrate the justifiability of the lack of accommodation. While these bans may be allowed, the historical inequalities in education and the socio-economic context in which the provision of excellent education still favours certain races must be weighed carefully against the school's religious vision.

Hairstyles are a more complex matter given their diversity. The article argues that disputes as to whether a hairstyle forms part of a culture are likely to become difficult given the porous and evolving nature of culture. Public and independent schools are rather urged to re-evaluate their codes of conduct. Codes that favour Eurocentric notions of neatness may indirectly discriminate on race, a completely untenable situation in a constitutional South Africa. These codes must be revised to celebrate and affirm our diversity rather than be used to exclude and alienate segments of society.

\section{INTRODUCTION}

"Cultures are living and contested formations. The protection of the Constitution extends to those for whom culture gives meaning, not only to 
those who happen to speak with the most powerful voice in the present cultural conversation."

In 2016, a furore erupted with allegations of discriminatory treatment of learners at Pretoria High School for Girls. A newspaper article, reminiscent of apartheid, reported that the school had deemed afros untidy and students were being forced to chemically straighten their hair. ${ }^{2}$ Shortly thereafter protests flared up at Sans Souci High School in Cape Town ${ }^{3}$ and Saint Michael's School for Girls in Bloemfontein ${ }^{4}$ around, amongst others, the schools controversially regulating the hair of black students. The 2016 school protests were elevated as they flared up amidst the ongoing protests for decolonised higher education institutions. ${ }^{5}$ Questions were asked about transformation in schools and their accommodation of diverse cultural beliefs, particularly in the face of increasingly diverse learner bodies.

The issue of the accommodation of learner's cultural and religious beliefs is not new and whether schools should allow Muslim learners to wear a headscarf at school has been a recurring question over the last few years. ${ }^{6}$

This article discusses the duty of public and independent schools to accommodate diverse cultural and religious beliefs. First, it sets out the legal framework that governs the issue by examining the relevant constitutional provisions and the national legislation enacted to prohibit discrimination, being the Promotion of Equality and Prevention of Unfair Discrimination $\mathrm{Act}^{\dagger}$ ("PEPUDA"). Thereafter it analyses the specific obligations of schools in terms of the South African Schools $\mathrm{Act}^{8}$ (hereinafter "the School's Act"). Finally, it examines how this legal framework impacts on the right of both

MEC for Education: Kwazulu-Natal v Pillay 2008 (1) SA 474 (CC) 54.

2 The Guardian "Racism Row over South Africa School's Alleged Hair Policy" (29 August 2016) https://www.theguardian.com/world/2016/aug/29/south-africa-pretoria-high-schoolfor-girls-afros (accessed 2018-03-20).

3 Mail and Guardian "Sans Souci Girls' High School Pupils Protest against 'Discriminatory' Code of Conduct" (1 September 2016) https://mg.co.za/article/2016-09-01-sans-souci-girlshigh-school-pupils-protest-against-discriminatory-code-of-conduct (accessed 2018-03-20).

4 Coetzee "Schoolgirls' Hair Drama Spills over to Bloemfontein" (30 August 2016) http://www.bloemfonteincourant.co.za/plans-construction-free-states-first-mother-childhospital-approved/ (accessed 2018-03-20).

5 The Conversation "What 'Decolonised Education' Should and Shouldn't Mean" (14 February 2017) http://theconversation.com/what-decolonised-education-should-and-shouldnt-mean72597 (accessed 2018-03-20); Mathume "South African Students Demand Free and Decolonised Education" (29 December 2016) https://www.dandc.eu/en/article/south-africanstudents-demand-free-and-decolonised-education (accessed 2018-03-20).

6 Pijoos "Muslim Girls have to Carry 'Concession Cards' to Wear Headscarf at Joburg School" (5 June 2017) https://www.news24.com/SouthAfrica/News/muslim-girls-have-to-carryconcession-cards-to-wear-headscarf-at-joburg-school-20170605 (accessed 2018-03-20); Nyoka and De Villiers "Principal Instructed to Allow Muslim Pupil to Wear Hijab" (6 June 2017) https://www.news24.com/SouthAfrica/News/principal-instructed-to-allow-muslimpupil-to-wear-hijab-20170606 (accessed 2018-03-20). Furthermore, in 2007 the Constitutional Court, in MEC for Education: Kwazulu-Natal v Pillay supra, decided on whether a public school unfairly discriminated against a Hindu learner by failing to allow the learner to wear a nose stud to school. In 2013, the Free State High Court, in Radebe v Principal of Leseding Technical School [2013] ZAFSHC 111, found that a public school had discriminated against a Rastafarian learner based on her religion by failing to allow the learner to wear dreadlocks at the school.

7 Act 4 of 2000.

8 Act 84 of 1996. 
public and independent schools to regulate dress and hairstyles through their code of conduct.

\section{LEGAL FRAMEWORK}

South Africa is a constitutional supremacy and the Constitution binds both public and private bodies. ${ }^{9}$ This section explains the rights to religion and culture, PEPUDA and the School's Act and their implications for school governing bodies to accommodate cultural and religious practices in their codes of conduct.

\section{Right to culture}

The South African Constitutional Court in Pillay held that "our Constitution does not tolerate diversity as a necessary evil, but affirms it as one of the primary treasures of our nation." ${ }^{.10}$ Diversity and difference are valued and protected in a range of provisions in the South African Constitution.

Section 30 of the Constitution protects the individual right to culture and protects the right of individuals to use the language and participate in the cultural life of their choice. ${ }^{11}$ Section 31 protects the group right to culture and provides that individuals have the right to enjoy their culture, practise their religion and use their language and form and maintain cultural, religious and linguistic associations. ${ }^{12}$ The group right contains an internal limitation clause which provides that it may not be exercised in a manner inconsistent with the Constitution ${ }^{13}$ and of course, remains subject to limitation in terms of the general limitation clause. ${ }^{14}$

Culture is an ambiguous notion and it is generally thought to be defined by factors such as shared language, religion or cultural practices. ${ }^{15}$ The Constitutional Court in Pillay suggested that it was broader than these notions but ultimately did not decide on its parameters. ${ }^{16}$ Ampofo-Anti and

9 S 8(1) of the Constitution of the Republic of South Africa, 1996 (hereinafter "the Constitution"). For a discussion of the horizontal application of rights see Chirwa "The Horizontal Application of Constitutional Rights in a Comparative Perspective" 200610 Law, Democracy and Development 21 37-45.

10 MEC for Education: Kwazulu-Natal v Pillay supra 92.

11 S 30 provides:

"Everyone has the right to use the language and to participate in the cultural life of their choice, but no one exercising these rights may do so in a manner inconsistent with any provision of the Bill of Rights."

12 S 31 provides:

"(1) Persons belonging to a cultural, religious or linguistic community may not be denied the right, with other members of that community-

(a) to enjoy their culture, practise their religion and use their language; and

(b) to form, join and maintain cultural, religious and linguistic associations and other organs of civil society.

(2) The rights in subsection (1) may not be exercised in a manner inconsistent with any provision of the Bill of Rights."

13 S 31(2) of the Constitution.

14 S 36 of the Constitution.

15 Bennett Customary Law in South Africa (2004) 86.

16 MEC for Education: Kwazulu-Natal v Pillay supra 48-49. 
Bishop note that courts often brush over questions such as: What is a culture? and Does the claimant and practice form part of the culture? because these questions are frequently not in dispute. ${ }^{17}$ They argue, however, that these may be important considerations in determining the limits of cultural accommodation. ${ }^{18}$ The authors offer a definition of a culture as follows: a group of people who may share certain characteristics like language or religion and certain beliefs and values, who consider themselves a culture and are recognised by others as a culture which may overlap with other cultures and whose members engage in practices because of their membership in a group that are heterogeneous and evolve over time. ${ }^{19}$ Furthermore, the determination of whether a claimant is a member of a cultural group is proposed to be answered through a combined subjective and objective test namely: (a) the claimant must view herself as a member of the culture; and (b) they must be accepted by at least some other members as part of that culture. ${ }^{20}$

The third question of whether the claimant's belief or practice forms part of the culture is the most relevant and contentious in practice. ${ }^{21}$ Arguably the two key questions needed to be asked are, first, whether a subjective or objective approach should be adopted in determining whether a practice forms part of a culture ? $^{22}$ Secondly, does the Constitution protect mandatory or voluntary cultural practices? ${ }^{23}$

Ampofo-Anti and Bishop argue, rightly in our view, that Langa CJ in Pillay refrained from answering the question of whether to adopt the subjective or objective approach on the basis that both approaches would lead to the same conclusion in the case. ${ }^{24}$ The authors acknowledge the dangers of adopting a purely subjective or objective approach and advocate a middle ground approach where the claimant is required to show that the practice is followed by a portion of the members of their culture who do so because of its cultural significance. ${ }^{25}$ They do not propose a fixed percentage of members of the culture who need to adhere to a cultural practice and this may vary depending on the facts of each case. ${ }^{26}$

17 Ampofo-Anti and Bishop "On the Limits of Cultural Accommodation: KwaZulu-Natal MEC for Education v Pillay: Part III: Reflections on Themes in Justice Langa's Judgments" 2015 Acta Juridica 456 462. The authors note that these questions were not considered in MEC for Education: Kwazulu-Natal v Pillay supra nor in Kievits Kroon Country Estate (Pty) Ltd v Mmoledi (2012) 33 ILJ 2812 (LAC) and Department of Correctional Services v Police and Prisons Civil Rights Union (POPCRU) 2013 (4) SA 176 (SCA), two recent cases involving claims for cultural exemptions.

18 Ampofo-Anti and Bishop 2015 Acta Juridica 463.

9 Ampofo-Anti and Bishop 2015 Acta Juridica 472-473.

Ampofo-Anti and Bishop 2015 Acta Juridica 471.

Ampofo-Anti and Bishop 2015 Acta Juridica 474.

Ibid.

Ibid.

Ampofo-Anti and Bishop 2015 Acta Juridica 476.

25 Ampofo-Anti and Bishop 2015 Acta Juridica 476-477. They argue that the approach is consonant with O'Regan J's minority judgment in Pillay where she held that "a court must investigate whether a practice is shared by the broader community, or portion of it, to qualify as a cultural practice rather than a personal habit or preference." See MEC for Education: Kwazulu-Natal v Pillay supra 154.

26 Ampofo-Anti and Bishop 2015 Acta Juridica 477. 
In light of the current jurisprudence on culture, it is unlikely that the definition of culture or whether an individual adheres to a culture will be disputed in courts. More likely courts will be called upon to decide whether a practice constitutes a cultural practice. In this regard, courts should arguably adopt the combined objective and subjective approach in line with that of O'Regan $\mathrm{J}$ in Pillay to determine whether "the claimant follows the practice because of its communal and associative role in constructing her identity, not her own personal preferences". ${ }^{27}$ Such an approach places limits on the right to culture and guards against individuals claiming every action as a cultural practice. At the same time, it accommodates the variable nature of culture which may be practised differently by individuals.

Given the variable nature of culture and that it is generally not prescriptively enforced on adherents, the right should be interpreted generously to protect voluntary practices. The reality is that most cultures are not as organised as religion and do not have obligatory requirements but rather practices which individuals choose to observe. ${ }^{28}$ Given the voluntary nature of cultural practices, protecting only mandatory practices would render the right to culture meaningless. ${ }^{29}$ The Constitutional Court in Pillay argued that voluntary practices are no less part of a person's identity and are likely to enhance a person's sense of identity, autonomy and dignity. ${ }^{30}$ This conforms to a constitutional obligation to celebrate diversity and not merely tolerate it. ${ }^{31}$ The voluntary/mandatory nature of the practice is perhaps more relevant in the determination of whether any discrimination is fair. ${ }^{32}$

The right to culture is important in South Africa today. For some individuals, cultural practices are as important as religious beliefs ${ }^{33}$ and are often central to an individual's self-identity and human dignity. ${ }^{34}$ For many individuals, they give a sense of belonging and value, and thus the right should not be underestimated. Despite the indeterminacy and ambiguous nature of the right to culture, it is central to an individual's identity and dignity and, therefore, interferences with the right must be carefully considered.

\section{Freedom of religion}

The right to culture often overlaps with the right to freedom of religion. The Constitutional Court in Pillay held that religious practices are often informed by cultural beliefs while cultural beliefs often have an underlying religious basis. ${ }^{35}$ Thus a single practice may constitute both a cultural and religious practice and it must be borne in mind that there is often a great deal of overlap between the rights to religion and culture.

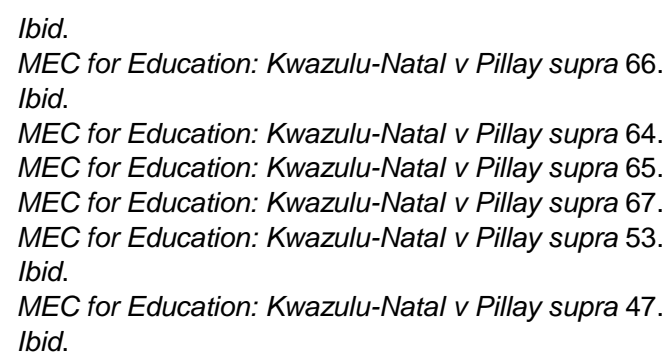


Section 15 of the Constitution provides for the freedom of religion, belief and opinion. ${ }^{37}$ Religious freedom protects beliefs which are often deeply personal and part of an individual's self-identity. David Conkle notes that while the content of religious beliefs may differ amongst individuals, the common and distinct nature of these beliefs is that they define an individual and provide the framework through which individuals evaluate conduct. ${ }^{38}$ This is because religious beliefs dictate in some instances, almost every aspect of an individual's life from their dress and diet to their purpose in life and what they consider acceptable behaviour. ${ }^{39}$

In South Africa, religious freedom entails the right to hold a belief and the right to manifest a belief. ${ }^{40}$ The manifestation of religious belief encompasses worship or observance, practice and teaching. ${ }^{41}$ Section 15(2) allows religious observances in state or state-aided institutions provided they are in accordance with the public authorities' rules, conducted on an equitable basis and attendance at them is voluntary. ${ }^{42}$ Like all other rights it is subject to the general limitation clause in section 36 of the Constitution.

In the determination of whether a practice is religious and worthy of protection, the court examines the sincerity of the claimant's beliefs. Religious freedom in South Africa protects voluntary conduct based on sincerely held religious beliefs. ${ }^{43}$ Barring any evidence that the claimant is acting fraudulently, the court accepts the claimant's profession regarding the practice. The court does not require the claimant to prove the objective requirements of their faith and courts are thought to be wholly ill-equipped to pronounce on the requirements of a religion which may be highly disputed issues.

The right to culture and religion are central to an individual's sense of selfidentity, autonomy and dignity. The protection extends to voluntary practices which enhance our autonomy and dignity. ${ }^{44}$ Infringements of the right need

315 of the Constitution.

8 Conkle "Toward a General Theory of the Establishment Clause" 1987-1988 82(4) NorthWestern University LR 1113 1164. See also Marshall "Truth and the Religion Clauses" 1993-1994 DePaul LR243 247.

39 For a discussion on the importance of the right see Osman Freedom of Religion and the Headscarf: A Perspective from International and Comparative Constitutional Law (Unpublished master's thesis University of Cape Town 2012) 9-14.

40 Prince $v$ President of the Law Society of the Cape of Good Hope 2001 (2) SA 388 (CC) 38 and Christian Education South Africa v Minister of Education 20004 SA 757 (CC) 19.

41 S v Lawrence; S v Negal; S v Solberg 1997 (4) SA 1176 (CC) 92.

42 For a comprehensive discussion of the right see Farlam "Freedom of Religion, Belief and Opinion" in Constitutional Law of South Africa (2008), Chapter 41.

43 MEC for Education: Kwazulu-Natal v Pillay supra 67. This approach accords with jurisprudence from the United States of America, Canada and Germany. See Thomas $v$ Review Board of the Indiana Employment Security Division 45 U.S 707 715-716; Syndicat Northcrest $v$ Amselem [2004] 2SCR 551, 2004 SCC 47 and Axel Frhr. Von Campenhausen "The German Headscarf Debate" 2004 Brigham Young University LR 665 678. For a discussion thereon see Osman Freedom of Religion and the Headscarf: A Perspective from International and Comparative Constitutional Law 29-31.

44 MEC for Education: Kwazulu-Natal v Pillay supra 64. S 10 of the Constitution provides that "[e]veryone has inherent dignity and the right to have their dignity respected and protected". In S v Makwanyane 1995 (3) SA 391 (CC) 84, Chaskalson P stated that the right to life and the right to dignity were, together "the source of all other rights". O'Regan $\mathrm{J}$ stated that: 
to be carefully evaluated as they often force adherents to make the difficult choice of abiding by their beliefs or attaining some benefit. Such interferences with the right would constitute discrimination and the court would have to consider whether the discrimination is fair and may be upheld.

\section{PEPUDA}

The constitutional right to equality states that no person may be unfairly discriminated against on the grounds of, amongst others, religion or culture ${ }^{45}$ and that legislation would be enacted to prevent such unfair discrimination. PEPUDA is the national legislation enacted to prevent unfair discrimination. Claims of unfair discrimination must be adjudicated in terms of the Act and parties cannot circumvent the legislation by direct reliance on the constitutional rights implicated. ${ }^{46}$ Discrimination may be established, however, by demonstrating an interference with rights to culture or religious

"Respect for the dignity of all human beings is particularly important in South Africa. For apartheid was a denial of a common humanity. Black people were refused respect and dignity and thereby the dignity of all South Africans was diminished. The new constitution rejects this past and affirms the equal worth of all South Africans. Thus, recognition and protection of human dignity is the touchstone of the new political order and is fundamental to the new constitution."

In Dawood v Minister of Home Affairs; Shalabi v Minister of Home Affairs; Thomas $v$ Minister of Home Affairs 2000 (3) SA 936 (CC) 35, the Court stated:

"The value of dignity in our Constitutional framework cannot therefore be doubted. The Constitution asserts dignity to contradict our past in which human dignity for black South Africans was routinely and cruelly denied. It asserts it too to inform the future, to invest in our democracy respect for the intrinsic worth of all human beings. Human dignity therefore informs constitutional adjudication and interpretation at a range of levels. It is a value that informs the interpretation of many, possibly all, other rights. This Court has already acknowledged the importance of the constitutional value of dignity in interpreting rights such as the right to equality, the right not to be punished in a cruel, inhuman or degrading way, and the right to life. Human dignity is also a constitutional value that is of central significance in the limitations analysis. Section 10, however, makes it plain that dignity is not only a value fundamental to our Constitution, it is a justiciable and enforceable right that must be respected and protected."

45 S 9(3) of the Constitution. In Fraser v Children's Court, Pretoria North 1997 (2) SA 261 (CC) 20 , Mahomed DP had the following to say with regards to the right to equality in the Constitution of the Republic of South Africa 200 of 1993 (the interim Constitution):

"There can be no doubt that the guarantee of equality lies at the very heart of the Constitution. It permeates and defines the very ethos upon which the Constitution is premised. In the very first paragraph of the preamble it is declared that there is a "[n]eed to create a new order ... in which there is equality between men and women and people of all races so that all citizens shall be able to enjoy and exercise their fundamental rights and freedoms". Section $8(1)$ guarantees to every person the right to equality before the law and to equal protection of the law. Section 8(2) protects every person from unfair discrimination on the grounds of race, gender, sex, ethnic or social origin, colour, sexual orientation, age, disability, religion, conscience, belief, culture or language. These specified grounds are stated to be without derogation from the generality of the provision. Section 8(3)(a) makes it clear that nothing in sections $8(1)$ or (2) precludes measures designed to achieve the adequate protection or advancement of persons or groups or categories of persons disadvantaged by unfair discrimination, in order to enable their full and equal enjoyment of all rights and freedoms."

46 MEC for Education: Kwazulu-Natal v Pillay supra 40. See also Currie and De Waal The Bill of Rights Handbook (2013) 245. 
freedom. ${ }^{47}$ The Act furthermore explicitly prohibits discrimination by both the state and private parties. ${ }^{48}$

Discrimination is defined in section 1 of PEPUDA as:

"any act or omission, including a policy, law, rule, practice, condition or situation which directly or indirectly-

(a) imposes burdens, obligations or disadvantage on; or

(b) withholds benefits, opportunities or advantages from, any person on one or more of the prohibited grounds".

Discrimination on the list of prohibited grounds, such as religion or culture, is presumed to be unfair and the onus is on the respondent to prove that the discrimination is fair. ${ }^{49}$ Section 14 PEPUDA sets out the test for the determination of fair discrimination:

"(1) It is not unfair discrimination to take measures designed to protect or advance persons or categories of persons disadvantaged by unfair discrimination or the members of such groups or categories of persons.

(2) In determining whether the respondent has proved that the discrimination is fair, the following must be taken into account:

(a) The context;

(b) the factors referred to in subsection (3);

(c) whether the discrimination reasonably and justifiably differentiates between persons according to objectively determinable criteria, intrinsic to the activity concerned.

(3) The factors referred to in subsection (2)(b) include the following:

(a) Whether the discrimination impairs or is likely to impair human dignity;

(b) the impact or likely impact of the discrimination on the complainant;

(c) the position of the complainant in society and whether he or she suffers from patterns of disadvantage or belongs to a group that suffers from such patterns of disadvantage;

(d) the nature and extent of the discrimination;

(e) whether the discrimination is systemic in nature;

(f) whether the discrimination has a legitimate purpose;

(g) whether and to what extent the discrimination achieves its purpose;

(h) whether there are less restrictive and less disadvantageous means to achieve the purpose;

(i) whether and to what extent the respondent has taken such steps as being reasonable in the circumstances to-

(i) address the disadvantage which arises from or is related to one or more of the prohibited grounds; or

(ii) accommodate diversity."

In addition, section 2 of the Schedule to PEPUDA lists practices that would be considered unfair in the education sector, namely:

"(a) Unfairly excluding learners from educational institutions, including learners with special needs.

\footnotetext{
MEC for Education: Kwazulu-Natal v Pillay supra 46.

$S 6$ of the PEPUDA.

49 S 13(2) as read with the definition of "prohibited grounds" in the PEPUDA.
} 
(b) Unfairly withholding scholarships, bursaries, or any other form of assistance from learners of particular groups identified by the prohibited grounds.

(c) The failure to reasonably and practicably accommodate diversity in education."

Both section 14 and the Schedule highlight the duty accommodation of diversity plays in the test for fairness. In explaining the notion of reasonable accommodation Langa $\mathrm{CJ}$ held that it sometimes requires an authority to take positive steps and even incur expenses to ensure individuals can enjoy their rights equally. ${ }^{50}$ In the context of employment law, the court warned of pushing to the edges of society those individuals who lack mainstream attributes $^{51}$ and that positive conduct may be required to accommodate diversity and those who fall outside the norm. ${ }^{52}$ The degree of accommodation required will depend on the facts of each case but the court suggested that more than a mere negligible effort would be required to ensure those outside the mainstream could swim freely in its waters. ${ }^{53}$ Langa $\mathrm{CJ}$ also held that accommodation is most appropriate, when the rule appears neutral but has a discriminatory effect and in schools and workplaces where competing interests can be more easily balanced. ${ }^{54}$

Therefore, in the context of dress codes at schools, it may be necessary for the school to ensure that they are taking positive steps to reasonably accommodate the learner so that that learner can enjoy their rights equally with other learners and thereby prevent unfair discrimination.

\section{South African Schools Act}

The Schools Act regulates school education in South Africa with the purpose of addressing past injustice in education and combating discrimination. ${ }^{55}$ Certain provisions apply only to public schools. Section 5(1) provides that public schools should not unfairly discriminate in any way. The Act does not define what constitutes "unfair discrimination" and this will most likely be interpreted in light of PEPUDA. Furthermore, the National Guidelines on School Uniform ${ }^{56}$ are meant to assist school governing bodies in the determination of a uniform. The Guidelines on School Uniform are not mandatory ${ }^{57}$ and arguably apply only to public schools as they were promulgated to assist governing bodies of public schools to adopt a code of conduct in terms of section 8(1) of the Act. They recommend that uniform policy "should take into account religious and cultural diversity within the community served by the school". ${ }^{58}$ Learners' religious beliefs should be

50 MEC for Education: Kwazulu-Natal v Pillay supra 73. For a discussion of Langa's approach see Ampofo-Anti and Bishop 2015 Acta Juridica 474.

MEC for Education: Kwazulu-Natal v Pillay supra 74.

52 MEC for Education: Kwazulu-Natal v Pillay supra 75.

53 MEC for Education: Kwazulu-Natal v Pillay supra 76.

54 MEC for Education: Kwazulu-Natal v Pillay supra 78.

55 Preamble of the South African Schools Act.

56 National Guidelines on School Uniforms (hereinafter "the Guidelines on School Uniform") GN 173 in GG 28538 of 2006-02-23.

57 National Guidelines on School Uniform par 34.

58 National Guidelines on School Uniform par 29(1). 
accommodated, and schools should not prohibit learners from wearing headscarves as part of a religious practice.

Furthermore, the National Policy on Religion and Education ${ }^{60}$ provides a framework for religious teaching and observance in public institutions and is not applicable to independent schools. ${ }^{61}$ The policy celebrates the diversity of the South African population and aims to ensure that no single religious ethos dominates others and that all religious views are recognised and respected in public schools. The policy recommends that when school governing bodies determine the policy for religious observance in schools, which includes dress, they do so in a manner that is consistent with the policy and applicable legislation. ${ }^{62}$

The constitutional provisions, PEPUDA and the Schools Act create a comprehensive framework for the prohibition of discrimination in South African schools. The framework promotes the celebration of diversity and the accommodation of minority practices in the educational sphere. It is against this background that policies that fail to accommodate the headscarf and hairstyles must be evaluated.

\section{Independent schools}

Section 29(3) of the Constitution allows for the establishment of independent schools and only prohibits discrimination by independent schools based on race. ${ }^{63}$ Independent schools may operate in their preferred medium of instruction and promote a specific cultural and religious ethos. ${ }^{64}$ It suggests that private schools have more latitude than public schools to discriminate in their admission requirements. ${ }^{65}$ This is re-enforced by section $46(3)$ of the Schools Act which provides that the Head of Department must register an independent school if it is satisfied that, amongst others, the school's admission policy does not discriminate on the basis of race. ${ }^{66}$ However,

59 National Guidelines on School Uniform par 29(2).

60 Department of Education "National Policy on Religion and Education" (2003) https://www.gov.za/sites/www.gov.za/files/religion_0.pdf (accessed 2018-03-20) (hereinafter "National Policy").

61 National Policy 8.

62 National Policy 22.

63 S 29(3) of the Constitution provides:

"Everyone has the right to establish and maintain, at their own expense, independent educational institutions that-

(a) do not discriminate on the basis of race;

(b) are registered with the state; and

(c) maintain standards that are not inferior to standards at comparable public educational institutions."

64 Woolman "Defending Discrimination: On the Constitutionality of Independent Schools that Promote a Particular, if not Comprehensive, Vision of the Good Life" 200718 Stellenbosch LR 3131.

65 Woolman 200718 Stellenbosch LR 37.

66 S 46(3) provides:

"A Head of Department must register an independent school if he or she is satisfied that-

(a) the standards to be maintained by such school will not be inferior to the standards in comparable public schools;

(b) the admission policy of the school does not discriminate on the grounds of race; and 
PEPUDA's prohibition on discrimination, discussed above, is much broader than this and it is unclear whether independent schools are equally bound by this. $^{67}$

The Constitution and PEPUDA apply to private individuals and by implication encompasses independent schools. PEPUDA provides that in the event of any conflict with any other law, PEPUDA prevails. ${ }^{68}$ Secondly, according to the canons of statutory interpretation, the more recent legislation prevails which in this case is PEPUDA. ${ }^{69}$ Woolman notes that while the Schools Act is a specific sectoral legislation, it does not provide that in the event of a conflict, it would prevail. ${ }^{70}$ Accordingly, he argues that PEPUDA which gives effect to constitutional provisions prevails and independent schools are prohibited from discrimination based on, amongst others, religion and culture. ${ }^{71}$ Where discrimination has occurred, the school must show that the discrimination is fair, taking into account the factors discussed above in the discussion on PEPUDA. Here independent schools have additional interests that should be taken into account such as the constitutional right of citizens to establish independent schools and whether the accommodation detracts from the particular religious and cultural ethos the school promotes.

\section{HEADSCARVES AND HAIRSTYLES}

In light of the legal framework set out above, the question is what autonomy do schools have to regulate dress and hairstyles? Do independent schools have greater independence in enacting their codes of conduct? These questions are addressed in reference to perhaps two of the most controversial practices: headscarves and hairstyles.

\section{The headscarf}

Bans on the headscarf are not new and have been the subject of controversial debate worldwide. ${ }^{72}$ Lenta notes that while there is some

(c) the school complies with the grounds for registration contemplated in subsection (2)."

67 For a discussion on this see Woolman 200718 Stellenbosch LR 39-40.

68 The relevant provisions of $s 5$ state:

"(2) If any conflict relating to a matter dealt with in this Act arises between this Act and the provisions of any other law, other than the Constitution or an Act of Parliament expressly amending this Act, the provisions of this Act must prevail.

(3) This Act does not apply to any person to whom and to the extent to which the Employment Equity Act, 1998 (Act 55 of 1998), applies."

69 Woolman 200718 Stellenbosch LR 40.

70 Ibid.

Ibid.

72 Leyla Sahin v Turkey App No 44774/98 (2006) 45 ILM 436; Dahlab v Switzerland App No 42393/98, 15 February 2001 and Dogru v France App No 27058/05 (2009) 49 EHRR 8. In 2004, France enacted a law prohibiting the wearing of clothing manifesting a religious affiliation in public schools which was known as the "French Headscarf Ban". See Welch "The Prohibition of the Muslim Headscarf: Contrasting International Approaches in Policy and Law" 200719 The Denning Law Journal 181 185. For a discussion of notable bans on 
debate as to whether the headscarf is a mandatory requirement in Islam, there are sufficient grounds to accept that Muslim women wear the headscarf out of a religious obligation and for the practice to be protected by the right to freedom of religion. ${ }^{73} \mathrm{~A}$ school code which prohibits the headscarf, or fails to make an exemption for Muslim learners to wear a headscarf forces Muslim students to choose between their religious beliefs and pursuing their education at the school and constitutes an interference with the right to freedom of religion.

\section{Public schools}

Schools are bound by the provisions of PEPUDA and Schools Acts which prohibit discrimination on any grounds. The refusal to allow Muslim learners to wear a headscarf is an interference with the right to freedom of religion and thus constitutes discrimination based on religion which is presumed to be unfair unless the school can show otherwise. As discussed earlier, in making this determination the court considers the position of the complainant in society, whether they were the victim of previous disadvantage, the nature of the discrimination, its impact, whether it achieves a legitimate purpose, and whether there are less restrictive means of achieving the purpose. The court seeks to understand the discrimination's impact on real people and the position an individual occupies in society.

Muslims are a minority in South Africa with just over one million Muslims out of a population of 54,4 million people. ${ }^{74}$ During apartheid, Christianity was favoured by the state at the expense of Islam and other religions ${ }^{75}$ and this disadvantage was compounded by the fact that Muslims are predominantly Indians and Coloureds, previously disadvantaged groups in South Africa. ${ }^{76}$ Furthermore, given the current worldwide climate of Islamophobia, Muslims remain a vulnerable minority group in the country.

Schools are likely to justify their refusal on the basis that it is necessary for discipline, uniformity or to ensure acceptable convention among the learners. ${ }^{77}$ However, this appears as a flimsy justification as there is no reason to believe that allowing learners to wear a headscarf would undermine discipline at schools. Furthermore, the headscarf may be incorporated into the uniform, and the colour and way the headscarf is worn can be prescribed by the school to ensure uniformity. Furthermore, the

the headscarf from around the world see Osman Freedom of Religion and the Headscarf: $A$ Perspective from International and Comparative Constitutional Law 70-83.

73 Lenta "Muslim Headscarves in the Workplace and in Schools" 2007124 South African Law Journal 296 299-300. Also see Osman "Legislative Prohibitions on Wearing a Headscarf: Are they Justified?" 201417 PER: Potchefstroomse Elektroniese Regsblad 1318 1324-1325.

74 According to Statistics South Africa "General Household Survey" Pretoria: Statistics South Africa, 2015 the total population is estimated as 54432000 and Muslims comprise 1.9 per cent of the total population.

75 Czeglédy "A New Christianity for a New South Africa: Charismatic Christians and the Post Apartheid Order" 2008 38(3) Journal of Religion in Africa 284289.

76 Vahed and Jeppie "Multiple Communities: Muslims in Post-apartheid South Africa" in Daniel, Southall and Lutchman (eds) State of the Nation: South Africa 2004-2005 (2005) 252 252-253.

77 MEC for Education: Kwazulu-Natal v Pillay supra 14. 
National Guidelines on School Uniform, while only a recommendation, explicitly mandates governing bodies to consider the religious beliefs of learners and refrain from prohibiting the headscarf worn in accordance with religious beliefs. $^{78}$

The failure to accommodate a headscarf in a school uniform imposes a very heavy burden on Muslim learners who wear it out of a sense of obligation. The purpose and the goals of discipline and uniformity at public schools could still be achieved by allowing the headscarf but prescribing the manner in which it is worn. In light of the Guidelines on School Uniform specifically proscribing a headscarf ban, it seems clear that a public school's uniform code that failed to accommodate the headscarf would amount to unfair discrimination and should not be upheld. ${ }^{79}$

\section{Independent schools}

An additional interest to be considered with independent schools is the reason for its establishment. Independent schools are frequently established on the basis of religious grounds and schools may refuse to accommodate the headscarf on the basis that it conflicts with their religious views. Such schools may very well wish to promote a particular religious ideology and view the headscarf, and the Islamic beliefs it represents, as a negation of these beliefs. Here, the religious freedom of individuals who wish to wear a headscarf must be balanced against the constitutional right individuals have to establish schools provided they do not discriminate on the basis of race. Woolman argues that provided the exclusionary practice is not primarily aimed at denying a segment of the population access to goods but the pursuit of a legitimate goal, such as a religious association, the practice should be considered fair discrimination. ${ }^{80} \mathrm{He}$ argues that all associations by their nature discriminate and we should not be overzealous in dismantling these institutions which have legitimate goals and make for a richer society.

Woolman's comments are persuasive and in the context of schools, it is easy to understand how religious minorities may wish to establish to preserve and promote their religious identity. Religious freedom and the desire of parents to educate their children in such a manner should weigh no less than the desire of Muslim girls to wear a headscarf. However, a complicating factor is the history of inequitable education in South Africa.

During apartheid, education was segregated by race and state spending on education differed vastly between races. In 1982, the state spent an average of R1211.00 on a White child compared to R771.00 on an Indian

78 National Guidelines on School Uniform par 29(2).

79 This is consistent with Lenta's argument that the failure to grant Muslim women an exemption to wear the headscarf in the work place would amount to unfair discrimination; see Lenta 2007124 South African Law Journal 312.

80 Woolman 200718 Stellenbosch LR 34.

81 lbid. 
child, R498.00 on a Coloured child, and R146.00 on a Black child. ${ }^{82}$ The result was that White public schools, which also benefited from the affluent White communities they served, were significantly better resourced and offered a better education than Black schools. ${ }^{83}$ The dawn of democracy has done very little to address these inequalities as the top performing public schools in the country remain former White public schools. ${ }^{84}$ Admission to these schools is largely based on catchment areas and where individuals live. This is problematic given that segregation amongst racial groups remains "exceptionally high" 85 and individuals for economic reasons, amongst others, continue to live in the former racially designated areas. ${ }^{86}$

Individuals who are ineligible for good public schools may thus send their children to independent schools not of their religious persuasion which offer a better quality of education than the accessible public schools or independent schools of their own religious persuasion. ${ }^{87}$ In a context where education is hailed as the best equaliser of inequality, should Muslim girls be precluded from attending these schools because they are not willing to forsake their headscarf? Furthermore, most Muslims are Indian or Coloured $^{88}$ and the lack of accommodation would disproportionately affect Indian or Coloured females and constitute indirect discrimination on race which independent schools are explicitly prohibited from engaging in terms of legislation.

There is no easy answer as to whether independent schools may legitimately refuse to accommodate Muslim girls wearing a headscarf and the answer is likely to differ depending on the particular school and the basis of its establishment. Independent schools established as religious schools may find it easier to justify refusing to accommodate the headscarf than schools that merely have a religious ethos. Schools should consider the reasons for their refusal and whether the wearing of a headscarf poses a real threat to their purposes. Where it does, schools should be empowered to enforce their dress codes to ensure the right to establish independent

82 McConnachie "Equality and Unfair Discrimination in Education" in Verieva, Thom and Hodgson (ed) Basic Education Rights Handbook - Education Rights in South Africa (2017) 9192.

83 Head of Department, Mpumalanga Department of Education v Hoërskool Ermelo 2010 (2) SA 415 (CC) 46.

84 Businesstech "Best Private and Public Schools in South Africa: Cost v Performance" (9 February 2016) https://businesstech.co.za/news/lifestyle/111863/best-private-and-publicschools-in-south-africa-cost-vs-peformance/ (accessed 2018-03-20).

85 Christopher "Urban Segregation in Post-apartheid South Africa" 200138 Urban Studies 449 449.

86 Fear of crime has also impacted spatial divisions within the country. Lemanski "A New Apartheid? The Spatial Implications of Fear of Crime in Cape Town, South Africa" 200416 Environment and Urbanization 101.

Eg, "Reclaim the City" is a Cape Town based campaign launched in 2016 which claims that African and Coloured people in the Cape Town continue to live in former Black and Coloured racially designated areas and due to financial constraints are unable to access the former White designated areas. See "Why Reclaim the City?" http://reclaimthecity.org.za /why-reclaim-the-city/ (accessed 2018-03-20).

87 The top performing independent schools are schools with a Christian ethos; Christopher "Urban Segregation in Post-apartheid South Africa" 200138 Urban Studies 449449.

88 Vahed and Jeppie in Daniel, Southall and Lutchman (eds) State of the Nation: South Africa 2004-2005 252-253. 
schools has true meaning and value but should do so mindful of the complex and very inequitable educational landscape in South Africa.

\section{Hairstyles}

Hairstyles represent a more complex issue. While the rights to religion and culture are porous, bans on particular hairstyles will most likely implicate the right to culture. In light of the discussion above on defining a cultural practice, courts are likely to overlook the question of whether a person belongs to a culture and concentrate on whether a hairstyle forms part of a culture. On the Ampofo-Anti and Bishop approach, discussed above, courts would need to consider whether the practice is followed by a portion of the members of the culture who do so because of its cultural significance. While a court may easily find that dreadlocks, braids or afros form part of an individual's culture, this may potentially become a very difficult issue for courts to evaluate. For example, in one media report a parent of a child who was told that his haircut did not comply with the school's code of conduct allegedly claimed that his son's haircut, which was shaved at the bottom and longer at the top and referred to as a "fade" or "step", was part of his culture. $^{89}$ Given the evolving nature of culture and its imprecise limits, courts may struggle to ascertain whether such a hairstyle has cultural significance or is simply a fashion statement.

\section{Public schools}

As discussed above, schools are prohibited from discrimination on the basis of culture by the Constitution, PEPUDA and Schools Act to which they are bound. If a hairstyle is found to be a cultural practise, a code of conduct that prohibits it or fails to accommodate it constitutes discrimination on the basis of culture and the onus is on the school to show the discrimination to be fair.

As with the headscarf, the rationale for banning certain hairstyles is most likely to promote discipline, uniformity and acceptable convention among the learners. A school's code of conduct is likely to prescribe how hair must be worn to achieve these goals. While some may refer generally to the hair being neat and tidy, others may detail the length of the hair, how it must be worn or tied, the colour of the hairband and so on. The difficulty in South Africa is that given our history the notion of neatness is often defined by Eurocentric norms with little accommodation for African hairstyles which are treated with disdain.

During the apartheid era, one of the most egregious tests employed to distinguish between individuals for the purposes of classifying them as "White" or "Coloured" was the "pencil test". A pencil was pushed through a person's hair and if it remained in place the person was deemed to have frizzy hair and classified as "Coloured". If the pencil fell the person was classified as "White". Frizzy hair was considered inferior while straight hair was positioned as the aspirational superior. Thus, the notion of what

89 Sokanyile "Boys-only School Accused of Racism over Hair Policy" (29 July 2017) https://www.iol.co.za/news/south-africa/western-cape/boys-only-school-accused-of-racismover-hair-policy-10535785 (accessed 2018-03-20). 
constitutes "neat" or "tidy" is often not objective and defined to the prejudice of Black learners. Hair remains an emotive and controversial subject and the effect of a failing to accommodate hairstyles that have cultural significance must be appreciated.

Where a hairstyle holds cultural significance for an individual or is part of their group identity, failure to accommodate it is likely to have a severe emotional impact on the individual. It undermines their identity, autonomy, dignity, sense of belonging and self-worth. The dangers of such alienation were clearly felt during the 2015-2017 protests in higher education institutions. While the protests started because of escalating costs of tertiary education, students also voiced frustration at institutions which they perceived as alienating and unwelcoming of their beliefs. Tertiary institutions were forced to have an honest look at their institutional culture and their accommodation of various cultural beliefs. These protests serve as a warning of the anger and frustration that festers when rights to culture and self-expression are undermined.

What does that mean for order and discipline at schools? Given the variety of hairstyles that may be claimed under culture, are schools effectively precluded from regulating attire and enforcing their codes of conduct? Does this open the floodgates to the avalanche of claims under cultural accommodation? This question was succinctly answered by the Constitutional Court in Pillay when it held-

"[l]f there are other learners who hitherto were afraid to express their religions or cultures and who will now be encouraged to do so, that is something to be celebrated, not feared. As a general rule, the more learners feel free to express their religions and cultures in school, the closer we will come to the society envisaged in the Constitution. The display of religion and culture in public is not a 'parade of horribles' but a pageant of diversity which will enrich our schools and in turn our country."

If South Africa is to be a true "rainbow" nation, assumed understandings of neatness and the priority of uniformity in a diverse society has to be questioned. Accommodations are necessary to allow those previously marginalised to express themselves and their culture. There is no definitive answer on the matter but schools should ask themselves if they have done enough to accommodate diverse beliefs and not merely tolerate them.

\section{Independent schools}

While independent schools may be established in the preservation of a certain cultural ethos, this does not give them a carte blanche to refuse to accommodate hairstyles with a cultural significance. Woolman states that the school would have to demonstrate that it was promoting and advancing a particular culture and that the discrimination was necessary to offer an education grounded in that culture. ${ }^{91}$ This is difficult given that cultures overlap and the expression of one may not necessarily detract from the other. For example, a school established in the pursuit of German culture

MEC for Education: Kwazulu-Natal v Pillay supra 107.

91 Woolman 200718 Stellenbosch LR 42. 
would be hard pressed to show that allowing learners to wear afros detracted from its objective.

Furthermore, failing to accommodate African hairstyles may fall foul of the prohibition of discrimination on the basis of race. While White learners are capable of adopting the hairstyles and also prohibited from doing so, they generally do not do so. The media reports point to the fact that Black learners were singled out for breaching their school's code of conduct. The hairstyles are predominantly worn by Black learners and a code that does not accommodate their hairstyle disproportionately affects Black students and constitutes indirect discrimination based on race. While these policies appear neutral and benign they can effectively be used to limit access to institutions on the basis of race and should in such instances be struck down.

A final consideration is whether parents who voluntarily agreed to a dress code at an independent school can later object to it. In this regard, individuals may agree to waive their rights including their cultural and religious freedom. However, individuals have a very limited choice if they wish to attend a top performing independent school as there are not a diverse range of schools to choose from and certainly none of the top schools is established for the preservation of Islamic/African culture and beliefs. Thus, individuals have no choice but to agree to what may be very alienating codes of conduct if they wish to attend these schools. Finally, where codes of conduct discriminate based on race, even indirectly, they must be struck down. Schools should not be allowed to shield these policies on the basis that individuals voluntarily agree to abide by them.

\section{$4 \quad$ CONCLUSION}

The events at schools throughout South Africa in 2016 have led to many questions regarding the codes of conduct at both public and independent schools. Since the Pillay case, schools cannot merely assert the goals of discipline and uniformity to justify refusals to accommodate cultural and religious practices. Courts will interrogate thoroughly these refusals and expect schools to reasonably accommodate the religious and cultural beliefs of their learners. Independent schools are not excluded from this scrutiny and while they may pursue specific religious and cultural practices, they must clearly illustrate their objectives and that their policies are necessary to achieve their objectives. Religious and cultural freedom which are central to an individual's dignity, identity and autonomy cannot be infringed lightly. Therefore, this may be an opportune moment for schools to re-look their codes of conduct and to honestly evaluate whether their codes reflect the spirit of the rainbow nation South Africa aspires to be. 